\title{
Bibliography of Finnish Population Research 1994
}

\author{
Gathered and edited by ULLA-MAIJA MATTILA
}

The bibliography covers mainly the literature on population research published in Finland during 1994. Included are independent publications, articles in periodicals and mainly nationwide statistics published in Finland as well as studies by Finnish authors published abroad. In general the bibliography excludes nonscientific articles in newspapers and weeklies as well as unpublished reports and academic theses. Also not included are studies presented at proceedings of conferences held in Finland if they were written abroad and treated subjects outside Finland. Neither are comparative studies where Finland not forms a substantial part included in the bibliography. Coverage is less complete in peripheral fields.

In principle the main divisions appearing in the Population Index have been used with added subdivisions better suiting Finnish circumstances. Studies covering several fields of demography, which should rightly be listed in two or more divisions, are included in only one division, i.e. in the division representing the primary field, on which the report is centered.

Lists of literature on population research have been published in Yearbooks II-IV of the Family Federation of Finland and since 1960 in the Yearbook of Population Research in Finland, at first every fourth year, then every second year and starting from 1992 every year.

\section{A. GENERAL POPULATION STUDIES AND THEORIES}

Koskinen, Seppo; Martelin, Tuija; Notkola, Irma-Leena; Notkola, Veijo; Pitkänen, Kari (ed.). Suomen väestö (Finland's population). 1994. 339 pp. Gaudeamus, Helsinki. ISBN 951662-599-1.

Koskinen, Seppo; Martelin, Tuija; Notkola, Irma-Leena; Notkola, Veijo; Pitkänen, Kari. Väestö tutkimuksen kohteena (Population as an object of research). In: Suomen väestö, edited by Seppo Koskinen et al. 1994. 11-18 pp. Gaudeamus, Helsinki.

Syrjälä, Jaana (ed.). Väestönkasvun monet kasvot: oppimateriaali maailman väestönkasvus- ta (Different aspects of world population growth: educational material on global population questions). 1994. 79 pp + video film: Valinnat ja vastuu (Choices and responsibility). Suomen YK-liitto, Helsinki.

Valkonen, Tapani. Suomen väestö ja sen muutokset (Finland's population and its changes). Suomen Lääkärilehti, vol. 49 , no. 17 , 1994. 1867-79 pp.

\section{B. REGIONAL POPULATION STUDIES}

Pitkänen, K. Kiteeläiset väestötilaston kuvaamina (Demography of the Kitee people). In: Pitäjä rajojen mailla - Kitee ja Rääkkylä vuoteen 1870 by P. Kauppinen et al. 1994. 14860 pp. Kitee Municipality, Jyväskylä.

\section{SPATIAL DISTRIBUTION}

Heikkilä, Elli (ed.). Alueellisen kehityksen uusi dynamiikka ja integraatio (New dynamics of the regional development and integration). Research Reports, no. 124.93 pp. University of Oulu, Research Institute of Northern Finland, Oulu. ISBN 951-42-3947-4. Sum in Eng.

Jussila, Heikki; Husa, Ritva; Segerstrål, Boris. Väestödynamiikka ja alueellinen kehitys: Botnia-verkoston kaupunkialueiden muutos 1960-1990 = Population dynamics and regional development: change in Bothnia network city-regions 1960-1990. Research Reports, no. 113. 1993. 95 pp. University of Oulu, Oulu. ISBN 951-42-3656-4.

\section{TRENDS IN POPULATION GROWTH AND SIZE}

Jutikkala, Eino. Sittenkin yli neljän miljoonan (More than four million, after all). In: Suomalaisten tarina, 3: rakentajien aika, edited by Jaakko Itälä et al. 1993. 15-17 pp. Kirjayhtymä, Helsinki. ISBN 951-26-3832-0.

Laakso, Seppo. Helsingin väestökehityksen vaihtoehdot 1994-2020 (The alternatives of the population development of Helsinki). Helsingin 
kaupungin tietokeskuksen keskustelualoitteita 1994 , no. 3. 84 pp. 1994 . Helsingin kaupunki, Tietokeskus, Helsinki. ISBN 951-772-574-4.

Lindgren, Jarl. Maapallon väestö kasvaa vielä kauan (Earth's population growth continues still for a long time). YK-tiedote, no. 1, 1994. 3-6 pp.

Malinen, Pekka. Väestö ja kehitys: vertaileva tutkimus kahden kehitysmaan, Kenian ja Mauritiuksen, erilaisesta väestönkasvusta ja kehityksestä sekä niiden syistä (Population and development: a comparative study on the different population growth and development of the two developing countries, Kenya and Mauritius, and their reasons). SITRAn julkaisusarja, no. 135 and Helsingin yliopiston sosiaalipolitiikan laitoksen tutkimuksia, no. 1. 1994. 248 pp. Suomen itsenäisyyden juhlarahasto and Helsingin yliopisto, Helsinki. ISBN 951563-309-5. Doctoral dissertation. Summary in Eng.

Nieminen, Mauri. Perhe-ennuste (Projection of family size). In: Suomalainen perhe, edited by Leena Kartovaara and Hannele Sauli. 1994. 47-53 pp. Statistics Finland, Helsinki.

Notkola, Veijo; Ryynänen, Markku. Väestönkehityksen ennustaminen ja tuleva väestönkehitys Suomessa sekä eräissä Euroopan maissa (Forecasting population development, and the future population development in Finland and in some European countries). In: Suomen väestö, edited by Seppo Koskinen et al. 1994. 265-98 pp. Gaudeamus, Helsinki.

Parkkinen, Pekka. Sadantuhannen vuosiluokista suuriin ikäluokkiin (From the cohorts of one hundred thousand to baby boom cohorts). Kansantaloudellinen aikakauskirja, vol. 90, no. 4, 1994. 531-36 pp.

Säntti, Riitta. Väestön kehitysnäkymät (An estimate of population development in Finland). Vanhustyö, no. 5, 1993. 13-16 pp.

\section{E. MORTALITY}

Kannisto, Väinö. Time lag in the change of lifestyle: a factor in mortality. In:International Population Confererence, Montreal 24 August - 1st September 1993, vol. 1. 1993. 469-73 pp. International Union for the Scientific Study of Population, Liège.

Kannisto, Väinö. Development of the oldestold mortality, 1950-1990: evidence from 28 developed countries. Monographs on Population Aging, no. 1. 1994. 108 pp. Odense University Press, Odense. ISBN 87-7838-015-4.

Koskinen, Seppo. Miesten ylikuolleisuus (Male excess mortality). Sosiaalivakuutus, vol. 32, no. 5. 1994. 15-17 pp. Sum in Swe and Eng.

Koskinen, Seppo. Origins of regional differences in mortality from ischaemic heart disease in Finland. NAWH Research Reports, no. 41. 1994. 212 pp. NAWH National Research and
Development Centre for Welfare and Health, Helsinki. ISBN 951-47-9600-4. Doctoral Dissertation.

Koskinen, Seppo; Martelin, Tuija. Kuolleisuus (Mortality). In: Suomen väestö, edited by Seppo Koskinen et al. 1994. 150-225 pp. Gaudeamus, Helsinki.

Koskinen, Seppo; Martelin, Tuija. Pourquoi les femmes sont-elles moins inégales que les hommes devant la mort? Une analyse des données finlandaises (Why are mortality differentials among women smaller than among men? An analysis of Finnish data). Population, vol. 49, no. 2. 1994. 395-13 pp.

Koskinen, Seppo; Martelin, Tuija. Why are socioeconomic mortality differences smaller among women than among men? Social Science \& Medicine, vol. 38, no. 10, 1994. 1385-96 pp.

Leino, P.; Notkola, V.; Savela, S.; Österman, $O$. The development of mortality among Finnish forest and construction workers in 1976-90: the effect of occupational mobility and socioeconomic status. In: 17 th International Conference of COINTRA, 1993. Volume 1. Helsinki, June 28-July 1, 1993. 197-203 pp. Varma Reinsurance, Helsinki.

Martelin, Tuija. Mortality by indicators of socioeconomic status among the Finnish elderly. Social Science \& Medicine, vol. 38, no. 9, 1994. 1257-78 pp.

Martelin, Tuija. Differential mortality at older ages: sociodemographic mortality differences among the Finnish elderly. Publications of the Finnish Demographic Society, no. 16. 1994. 95 pp. ISBN 951-95357-7-2. Doctoral dissertation.

Martikainen, $P$. Socioeconomic factors and mortality among Finnish women 1981-5. PhD at the London School of Economics and Political Science. 1994. (See p. 105 in this yearbook).

Notkola, V.; Martikainen, $P$.; Leino, $P$. Time trends in mortality in forestry and construction workers in Finland 1970-85 and impact of adjustment for socioeconomic variables. Journal of Epidemiology and Community Health, vol. 47. 1993. 186-91 pp.

Notkola, Veijo; Pajunen, Airi; Leino, Päivi. Ammatillinen liikkuvuus ja kuolleisuus -metsätyöntekijöiden, maanviljelijöiden ja rakennustyöntekijöitten kuolleisuudesta Suomessa 1986-1990 (Occupational mobility and mortality: a study of mortality among Finnish forestry workers, farmers and construction workers in 1986-90). Sosiologia, vol. 31, no. 2. 1994. 112 22 pp. Sum in Eng.

Pekkanen, Juha; Nissinen, Aulikki; Vartiainen, Erkki; Salonen, Jukka T.; Pansar, Sven; Karvonen, Martti J. Changes in serum cholesterol level and mortality: a 30-year follow-up: the Finnish cohorts of the Seven Countries Study. American Journal of Epidemiology, vol. 139, no. 2, 1994. 155-65 pp.

Pitkänen, Kari; Mielke, James H. Age and 
sex differentials in mortality during two nineteenth century population crises. European Journal of Population, vol. 9, no. 1, 1993. 1-32 pp. Sum in Fre.

Pyörälä, K.; Palomäki, H.; Miettinen, H.; Mustaniemi, H.; Salomaa, V.; Valkonen, T. Decline in coronary heart disease mortality in Finland: effect on age and gender distribution of the disease. The American Journal of Geriatric Cardiology, vol. 3, no. 3, 1994. 20-32 pp.

Valkonen, Tapani. Health-related behaviours and their mortality consequences. In: International Population Conference, Montreal $24 \mathrm{Au}-$ gust - 1st September 1993, vol. 1. 1993. 44347 pp. International Union for the Scientific Study of Population, Liège.

Valkonen, Tapani. Trends and inequalities in mortality. In: Welfare trends in the Scandinavian countries, edited by E.J. Hansen et al. 1993. 305-19 pp. M.E. Sharpe, Armonk, NY.

Valkonen, Tapani. Socio-economic mortality differences in Europe. NIDI Hofstee lecture series, no. 1. 1993. 9-41 pp. Netherlands Interdisciplinary Demographic Institute NIDI, the Hague.

Valkonen, Tapani. Aiheuttaako työttömyys ennenaikaista kuolleisuutta (Does unemployment cause premature mortality). Suomalainen tiedeakatemia, Vuosikirja 1992-1993. 1993. 143-148 pp.

Valkonen, Tapani. Le ineguaglianze sociali nella salute nei paesi Europei: testimonianze e tendenze. In: L'equita nella salute in Italia, edited by G. Costa and F. Faggiano. 1994. 79-102 pp. Fondazione Smith Kline. Franco Angeli, Milano.

Valkonen, Tapani. Socio-economic mortality differences in Europe. In: Population and family in the Low Countries 1993: late fertility and other current issues, edited by Gijs Beets et al. NIDI/CBGS Publication, no. 30, 1994. 127-50 pp. Swets and Zeitlinger, Berwyn, Pennsylvania/Amsterdam, Netherlands.

Vartiainen, Erkki; Puska, Pekka; Pekkanen, Juha; Tuomilehto, Jaakko; Jousilahti, Pekka. Changes in risk factors explain changes in mortality from ischaemic heart disease in Finland. British Medical Journal, vol. 309, no. 6946, 1994. 23-7 pp.

Vartiainen, Erkki; Puska, Pekka; Pekkanen, Juha; Tuomilehto, Jaakko; Lönnqvist, Jouko; Ehnholm, Christian. Serum cholesterol concentration and mortality from accidents, suicide and other violent causes. British Medical Journal, vol. 309, no. 6952, 1994. 445-7 pp.

\section{F. FERTILITY}

Juntunen, Kaisa; Hartikainen-Sorri, AnnaLiisa. Ensisynnyttäjä kaksikymmentävuotta sitten ja nyt Pohjois-Suomessa (Primipara in Northern Finland twenty years ago and today).
Sosiaalilääketieteellinen Aikakauslehti, vol. 30, no. 1. 1993. 3-9 pp. Sum in Eng.

Kokkonen, Paula. Raskauden keskeyttämisen edellytykset ja käsittely Terveydenhuollon oikeusturvakeskuksessa (Preconditions and treatment of abortion in the National Board of Medicolegal Affairs). In: Raskauden keskeyttäminen - suomalaisia valintoja 1990-luvulla, edited by Matti Rimpelä and Maija Ritamo. Raportteja, no. 126.1993.171-74 pp. STAKES, Helsinki.

Koponen, Päivikki. Perhesuunnittelupalvelut väestövastuisessa perusterveydenhuollossa (Family planning services in basic health service). In: Raskauden keskeyttäminen - suomalaisia valintoja 1990-luvulla, edited by Matti Rimpelä and Maija Ritamo. Raportteja, no. 126. 1993. 149-55 pp. STAKES, Helsinki.

Kosunen, Elise. Tuloksellista perhesuunnittelua 1970-1980-luvuilla - pettävätkö palvelut 1990-luvulla? (Fruitful family planning in the 1970 s and 1980 s - do the services fail in the 1990s). In: Raskauden keskeyttäminen - suomalaisia valintoja 1990-luvulla, edited by Matti Rimpelä and Maija Ritamo. Raportteja, no. 126. 1993. 133-43 pp. STAKES, Helsinki.

National Research and Development Centre for Welfare and Health. The development of family planning services up to the year 2000: report of the working group. Themes 1994, no. 6. 1994. $11+6$ pp. Helsinki. ISBN 951-47-9281-5.

Notkola, Irma-Leena. Hedelmällisyys (Fertility). In: Suomen väestö, edited by Seppo Koskinen et al. 1994. 64-106 pp. Gaudeamus, Helsinki.

Notkola, Irma-Leena. Suomalaisten suhtautuminen aborttiin (The attitudes of the Finns on abortion). In: Raskauden keskeyttäminen suomalaisia valintoja 1990-luvulla, edited by Matti Rimpelä and Maija Ritamo. Raportteja, no. 126. $1993.87-102$ pp. STAKES, Helsinki.

Rimpelä, Matti; Ritamo, Maija (ed.). Raskauden keskeyttäminen - suomalaisia valintoja 1990-luvulla: raportti Sosiaali- ja terveysalan tutkimus- ja kehittämiskeskuksen, Terveydenhuollon oikeusturvakeskuksen, Folkhälsanin ja Väestöliiton Helsingissä 14.9.1993 järjestämästä seminaarista (Abortion - Finnish choices in the 1990s). Raportteja, no. 126. 1993. 232 pp. STAKES Sosiaali- ja terveysalan tutkimus- ja kehittämiskeskus, Helsinki. ISBN 951-47-7726-3.

Relethford, John H.; Mielke, James H. Marital exogamy in the Aland islands, Finland, 1750-1949. Annals of Human Biology, vol. 21, no. 1, 1994. 13-21 pp.

Rimpelä, Arja. Ehkäisystä keskeytykseen epidemiologinen katsaus (From contraception to abortion - an epidemiological review). In: Raskauden keskeyttäminen - suomalaisia valintoja 1990-luvulla, edited by Matti Rimpelä and Maija Ritamo. 1993. 31-49 pp. Raportteja, no. 126. STAKES, Helsinki. 
Ritamies, Marketta. Suunnittelemattomien raskauksien vähenemiseen vaikuttavat tekijät (Factors reducing unplanned pregnancies). In: Raskauden keskeyttäminen - suomalaisia valintoja 1990-luvulla, edited by Matti Rimpelä and Maija Ritamo. 1993. 51-67 pp. Raportteja, no. 126. STAKES, Helsinki.

Ritamies, Marketta. Finland. In: Abortion in the New Europe: a comparative handbook. 1994. 85-99 pp. Greenwood Press, Westport CT. ISBN 0-313-28723-6.

Salmi, Lauri. Perheen lapsiluvun suunnitteluun vaikuttavat tekijät: tutkimus turkulaisista naisista (The factors affecting the planned number of children of a family: study on women living in Turku). Annales universitatis turkuensis, ser C, tom. 102. 1994. 77 pp. + Appendix. Turun yliopisto, Turku. ISBN 95129-0270-2. Doctoral dissertation. Summary in Eng.

Sosiaali- ja terveysalan kehittämis- ja tutkimuskeskus. Perhesuunnittelupalvelujen kehittäminen vuoteen 2000: työryhmän raportti. Aiheita 1994, no. 3. 1994. 19 pp. Helsinki. ISBN 951-47-8521-5.

Säävälä, Minna. Naisten koulutus ja perhesuunnittelu (The education of women and family planning). YK-tiedote, no. 1, 1994. 16-17 pp.

Taimio, Hilkka. Lasten hankkiminen: taloustieteellinen näkökulma (Having children: an economic point of view). Hyvinvointikatsaus, no. 1, 1994. 23-27 pp.

Toivonen, Juhani. Sterilointi (Sterilization). In: Raskauden keskeyttäminen - suomalaisia valintoja 1990-luvulla, edited by Matti Rimpelä and Maija Ritamo. Raportteja, no. 126. 1993. 127-30 pp. STAKES, Helsinki.

Uitto, J.I. Fertility transition and socio-economic change in Western Kenya. African Studies Monographs, vol. 13, no. 4, 1992. 185201 pp.

Uitto, J.I. Fertility transition and socio-economic change in the developing world: overview and assessment of interlinkages. Svensk Geografisk Årsbok 1993. 156-69 pp.

Vuorenmaa, Hilkka. Perhekasvatusta ja seksuaalivalistusta Meksikon nuorille (Family and sex education to the youth of Mexico). YK-tiedote, no. 1, 1994. 20-21 pp.

Väestöliitto, the Family Federation of Finland. The evolution of reproductive health in Finland: how we did it. 1994.30 pp. Väestöliitto, Helsinki. ISBN 952-9605-06-4.

\section{G. NUPTIALITY AND THE FAMILY}

Csernak, J. Hazasodasi szokasok Finnorszagban es Magyarorszagon (Marriage trends in Finland and Hungary). Statistisztikai Szemle, vol. 71, no. 10, 1993. 782-806 pp.

Hulkko, Jouko. Avioliitto perustuu kumppanuuteen (Marriage is grounded on companion- ship). In: Suomalaisten tarina, 4: järjestelmien aika. 1993. 30-40 pp. Kirjayhtymä, Helsinki.

Häggman, Kai. Perheen vuosisata (The century of family: the ideal family and bourgeois lifestyle in nineteenth-century Finland). Historiallisia tutkimuksia, 179. 1994. $255 \mathrm{pp}$. Suomen Historiallinen Seura, Helsinki. 951-8915-85-7. Doctoral dissertation. Summary in Eng.

Kartovaara, Leena; Sauli, Hannele (ed.). Suomalainen perhe (The Finnish family). Population 1994:5. 1994. 192 pp. Statistics Finland, Helsinki. ISBN 951-47-8723-4.

Kartovaara, Leena. Perheen rakenne ja sen kehitys (The structure of family and its development). In: Suomalainen perhe, edited by Leena Kartovaara and Hannele, Sauli. 1994. 10-28 pp. Statistics Finland, Helsinki.

Kartovaara, Leena. Yksinhuoltajaperheet (Lone-parent families). In: Suomalainen perhe, edited by Leena Kartovaara and Hannele Sauli. 1994. 57-62 pp. Statistics Finland, Helsinki.

Lindgren, Jarl; Ritamies, Marketta. Parisuhteet ja perhe (Couple relationships and family). In: Suomen väestö, edited by Seppo Koskinen et al. 1994. 107-49 pp. Gaudeamus, Helsinki.

Linna, Pirkko (ed.). Perhe (Family). Sosiaalipolitiikan laitoksen tutkimuksia, sarja C, no. 6. 1994.188 pp. Tampereen yliopisto, Tampere. ISBN 951-44-3612-1.

Markkola, Pirjo. Työläiskodin synty: tamperelaiset työläisperheet ja yhteiskunnallinen kysymys 1870 -luvulta 1910-luvulle (The making of the working-class home: the question of working-class families in Finland, 1870 s through 1910s). Historiallisia tutkimuksia, no. 187. 1994. 271 pp. Suomen historiallinen seura, Helsinki. ISBN 951-710-001-9. Doctoral dissertation. Sum in Eng.

Moring, Beatrice. Skärgårdsbor: hushåll, familj och demografi i finländsk kustbygd på 1600-, 1700- och 1800-talen (Household, family and demography in Finnish coastal regions during the 17 th, 18 th and 19 th centuries). Bidrag till kännedom av Finlands natur och folk, no. 145.173 pp. Finska Vetenskaps-Societeten, Helsingfors. ISBN 951-653-265-9. Doctoral dissertation. Sum in Eng.

Nikander, Timo. Perheiden elämänkaari (Life cycle of families). In: Suomalainen perhe, edited by Leena Kartovaara and Hannele Sauli. 1994. 31-43 pp. Statistics Finland, Helsinki.

Sauli, Hannele. Lapset hajoavissa perheissä (Children in families breaking up). In: Suomalainen perhe, edited by Leena Kartovaara and Hannele Sauli. 1994. 63-64 pp. Statistics Finland, Helsinki.

Veikkola, Eeva-Sisko; Lehtiniemi, Anne. Naiset ja miehet Suomessa 1994 (Women and men in Finland in 1994). Living Condition 1994, no. 2. 1994. 109 pp. Statistics Finland, Helsinki. ISBN 951-47-8732-3. 
Vikat, Andres. Family formation in Estonia. Publications of the Finnish Demographic Society 1994 , no. 15. 1994. 176 pp. Finnish Demographic Society, Helsinki. ISBN 951-95357-64. Doctoral dissertation.

\section{H. MIGRATION}

\section{International migration}

Alitolppa-Niitamo, Anne. Somalipakolaiset Helsingissä: sosiaaliset verkostot ja klaanijäsenyyden merkitys. Sosiaali- ja terveysministeriön selvityksiä 1994 , no. 10. 1994. 60 pp. Sosiaali- ja terveysministeriö, Helsinki. ISBN 951-47-9926-7.

Alitolppa-Niitamo, Anne. Somali refugees in Helsinki: focus on social networks and the meaning of clan membership. 1994.60 pp. Ministry of Social Affairs and Health. ISBN 95147-9927-5.

Asker, Björn. Invandrare i tvåkammarriksdagen 1867-1970 (Immigrants at the two-chamber parliament in 1867-1970). Personhistorisk tidskrift, vol. 89, no. 1-2, 1993. 73-80 pp.

Birt, Hazel Lauttamus. The Finns of New Finland 1888-1993. 1993. 79 pp. Hazlyn Press, Winnipeg. ISBN 0-9693024-6-0.

Domander, Minna. Kulttuuritausta ja maahanmuuttajakoulutuksen tuloksellisuus (Cultural background and the fruitfulness of the immigrant education). Siirtolaisuustutkimuksia A, no. 17. 1994.116 pp. Siirtolaisuusinstituutti, Turku. ISBN 951-9266-47-X.

Engman, Max. The tug of war over "Nya Sverige". The Swedish-American Historical Quarterly, vo. 45, no. 2, 1994.69-117 pp.

Finnish American Historical Society of the West. Red Lodge Finns. Pioneer series, vol. 21, no. 1. $1993.58+1$ pp.

Hakovirta, Harto. Reforming the global refugee regime: an application and test of regime theory. Kansainvälisten suhteiden julkaisuja C, Työpapereita, 1. 1993. 20+4 pp. Lapin yliopisto, yhteiskuntatieteiden tiedekunta, Rovaniemi. ISBN 951-634-347-3.

Hakovirta, Harto. The global refugee problem: a model and its application. Kansainvälisten suhteiden julkaisuja. E, Eripainoksia, no. 1. 1993. 25 pp. Lapin yliopisto, Rovaniemi. ISBN 82-7541-074-6.

Heikkilä, Elli. Euroopan integraation vaikutus muuttoliikkeeseen (The effects of European integration on migration). In: Kainuu Euroopan kynnyksellä - puheenvuoroja alueista, taloudesta ja ympäristöstä, edited by Esko Toiviainen. Working Papers, no. 106. 1994. 10-12 pp. University of Oulu, Research Institute of Northern Finland, Oulu.

Heikkilä, Elli; Puistosalo, Pekka; Korhonen, Sirpa. Osaajat, liikkuvuus ja kansainvälistyminen (The skilled, migration and internationali- zation). In: Alueellisen kehityksen uusi dynamiikka ja integraatio, edited by Elli Heikkilä. 1994. 55-61 pp. Research Reports, no. 124. University of Oulu, Research Institute of Northern Finland, Oulu.

Hirstiö-Snellman, Paula. Maahanmuuttajat Helsingin Seudulla (Immigrants in the Helsinki region). Helsingin kaupungin tietokeskuksen tutkimuksia 1994, no. 9. 1994. $142+3$ pp. Helsingin kaupunki, Tietokeskus, Helsinki. ISBN 951-772-490-X.

Häikiö, Martti. Ruotsiin, Ruijaan ja Kanadaan (To Sweden, Finnmark and Canada). In: Suomalaisten tarina, 3: rakentajien aika, edited by Jaakko Itälä et al. 1993. 43-44 pp. Kirjayhtymä, Helsinki.

Häikiö, Martti. Ruotsin asuttajat ja paluumuuttajat (The settlers of Sweden and the return migrants). In: Suomalaisten tarina, 4: järjestelmien aika, edited by Jaakko Itälä, et al. 1993. 24-25 pp. Kirjayhtymä, Helsinki.

Karjalainen, Elli. Muuttoliikkeen kehityslinjat USA:n länsirannikolla (Development of migration in the West-Coast of USA). Lompolo, no. 1, 1993. 29-32 pp.

Kavén, Pertti. 70000 små öden: Finlands krigsbarn (70 000 small fates: Finnish child refugees during World War II). 1994. 179 pp. Sahlgren, Otalampi.

Koivukangas, Olavi. Suomen valtamerentakainen siirtolaisuus (Finland's emigration across the oceans). Siirtolaisuus, vol. 21 , no. 3, 1994. 26-34 pp.

Korkiasaari, Jouni. Suomalaiset Euroopassa (The Finns in Europe). Siirtolaisuus, vol. 21, no. 3, 1994. 35-42 pp.

Korkiasaari, Jouni; Söderling, Ismo. Muuttoliike (Migration). In: Suomen väestö, edited by Seppo Koskinen et al. 1994. 226-64 pp. Gaudeamus, Helsinki.

Koskinen, Arja. Borte men også hjemme: om finske innvandrerkvinners liv i Nord-Norge (Away but also at home: on the life of Finnish immigrant women in northern Norway). FDHrapport, 11; Alberte, 5). 1993. 50 pp. Finnmark distriktshögskole, Alta. ISBN 82-7541-074-6.

Kultalahti, Olli. Internationalization and migration pressure. Siirtolaisuus, vol. 21 , no. 3, 1994. 7-25 pp.

Kulu, Hill. Estonians in the world: an overview of number and localization 1850-1990. Siirtolaisuus, vol. 20 , no. 2, 1993. 3-12 pp.

Laakkonen, Risto. Kansaninvälinen muuttoliike tänään (International migration today). YK-tiedote, no. 2, 1994. 3-7 pp.

Laari, Outi. Onko Suomessa sijaa ulkomaalaisille? (Is there room for foreigners in Finland?). Siirtolaisuus, vol. 21, no. 2, 1994. 13-20 pp.

Liebkind, Karmela (ed.). Maahanmuuttajat: kulttuurien kohtaaminen Suomessa (Immigrants: the facing of two cultures). 1994. $240 \mathrm{pp}$. Gaudeamus, Helsinki. ISBN 951-662-600-9. 
Majava, Altti. The reshaping of Europe: implications for migration from a Nordic perspective. In: Recent migration trends in Europe, Europe's new architecture, edited by M.B. RochaTrindade. 1993. 135-54 pp. Universidade Aberta, Instituto Estudos Para O Desenvolvimento, Lisbon.

Maki, Jeanne C. Third generation exiles come home. Finnish-Americana, vol. 10, 1993 1994. 1993. 6-17 pp.

Nieminen, Mauri. Ulkomaalaiset Suomessa: tilastotietoa Suomen ulkomaalaisväestöstä (Foreigners in Finland: statistical data on foreigners in Finland). Population 1994, no. 3. 1994. 36 pp. Statistics Finland, Helsinki. 951-47-8720-X.

Pennanen, Helena. Naisen asema ja suomalaisnaisten sopeutuminen Hollannissa (The social position and acculturation of Finnish women in Holland). Siirtolaisuus, vol. 20, no. 2. 1993. 18-25 pp. Sum in Eng.

Pitkänen, K.J. The road to survival or death? Temporary migration during the Great Finnish Famine in the 1860s. In: Just a sack of potatoes?: Crisis experienced in European societies, past and present, edited by A. Häkkinen. 1992. 87-118 pp. Studia Historica 44. Suomen Historiallinen Seura, Helsinki.

Runblom, Harald. Invandrare i svensk historia: individ och kollektiv (Immigrants in the Swedish history: individual and collective). Personhistorisk tidskrift, vol. 89, no. 1-2, 1993. 7380 pp.

Runtti, Susanna. På flykt till grannen (Flight to the neighbours). 1994.96 pp. Kulturfonden för Sverige och Finland, Esbo. ISBN 95196682-2-5.

Runtti, Susanna. Naapuriin evakkoon (Flight to the neighbours). $1994.95 \mathrm{pp}$. Suomalais-ruotsalainen kulttuurirahasto, Espoo. ISBN 95196682-1-7.

Takalo, Pirjo. Inkerinsuomalaiset paluumuuttajina: selvitys inkerinsuomalaisten integraatiosta ja viranomaispalveluiden käytöstä (Ingrians as return migrants: study on their integration and use of services of the authorities). Sosiaali- ja terveysministeriön monisteita 1994 , no. 20.1994 .66 pp. Sosiaali- ja terveysministeriö, Helsinki. ISBN 951-47-9668-3.

Valtonen, Kathleen. Towards an understanding of the Vietnamese refugee situation. Siirtolaisuus, vol. 20, no. 4, 1993. 3-10 pp.

Verigin, Sergei; Suni, Leo. Inkerinsuomalaisten muutto Karjalaan 1940-luvun lopussa (The move of the Ingrian Finns to Karelia at the end of the 1940s). Carelia, no. 6, 1993. 143-49 pp.

Walter, Hannes. Emigranttien osuus Viron Tasavallan restauraatiossa (The share of emigrants in the restauration of Estonia). Kotiseutu, no. 3, 1993. 80-86 pp.

\section{Internal migration}

Heikkilä, Elli. Vanhukset ja muuttoliike
(Elderly people and migration). Siirtolaisuus, vol. 20, no. 4, 1993. 17-21 pp. Sum in Eng.

Hämynen, Tapio. Evakuointia, sotavankeutta, takaisinpaluuta ja uudelleenasuttamista (Evacuation, captivity, return and resettlement). Rajaseutu, vol. 71, no 3, 1994. 9 $11 \mathrm{pp}$.

Hämynen, Tapio. Liikkeellä leivän ja aviopuolison tähden: avioliitot kuvastavat työssäkäynnin suuntaa Raja-Karjalassa 1880-1918 (On the move after bread and spouse: marriages reflect the direction of going to work in Karelia near the border). Sukuviesti, no. 1, 1994. 4$6 \mathrm{pp}$.

Karjalainen, Elli. Structure of migration flows in Kainuu, Finland. In: The urban population at a microscale, edited by Alina Potrykowska and Piotr Korcelli. 1994. 317-28 pp. Geographica Polonica, 61. Polish Academy of Sciences.

Korhonen, Sirpa. Paluumuuttohalukkuus Kainuuseen: tutkimus Kainuusta 1982-90 muuttaneista henkilöistä $=$ Willingness to return migration to Kainuu: a research of the migrants from Kainuu 1982-90. Research reports, 120. 1994. 113 pp. University of Oulu, Research Institute of Northern Finland, Oulu. ISBN 951-423803-6.

Mielke, James H.; Relethford, John H.; Eriksson, Aldur W. Temporal trends in migration in the Aland Islands: effects of population size and geographic distance. Human Biology, vol. 66 , no 3, 1994. 399-410 pp.

Ojanperä, Satu. When people have to move away: resettlement as part of erosion control in Nacala, Mozambique. 1994. 70 pp. Ministry of the Environment, Helsinki. ISBN 951-47-88540 .

Rikkinen, Kalevi. Suomalainen asuttaa maaseutua ja kasvattaa taajamia samanaikaisesti (The Finns settle the countryside and municipalities at the same time). In: Suomalaisten tarina, 3: rakentajien aika, edited by Jaakko Itälä et al. 1993. 37-42 pp. Kirjayhtymä, Helsinki.

Saarelainen, Asko. Sodanjälkeinen asutustoiminta Pielisjärven maaseudun muovaajana (Resettlement after the Second World War as former of the rural district of Pielisjärvi). Rajaseutu, vol. 71, no. 3. 1994. 12-14 pp.

\section{HISTORICAL DEMOGRAPHY AND DEMOGRAPHIC HISTORY}

Jutikkala, Eino. Frost or microbes. Scandinavian History Review, vol. 41, no. 1, 1993. 73 $79 \mathrm{pp}$.

Pitkänen, Kari. Suomen väestön historialliset kehityslinjat (The historical development of the Finnish population). In: Suomen väestö, edited by Seppo Koskinen et al. 1994. 19-64 pp. Gaudeamus, Helsinki. 


\section{J. CHARACTERISTICS}

Heikkilä, Elli. Väestön ikääntymisen alueelliset kehityspiirteet Suomessa (The regional features of development of population aging in Finland). Terra, vol. 106, no. 4, 1994. 374-83 pp.

Hulkko, Jouko. Ikääntyvä Suomi (Aging Finland). In: Suomalaisten tarina, 4: järjestelmien aika 1968-1990, edited by Jaakko Itälä et al. 1993. 19-23 pp. Kirjayhtymä, Helsinki. ISBN 951-26-3833-9.

Karjalainen, Elli. Swedish-speaking population as an ethnic group in Finland. In: Geography and ethnicity, edited by Anton Gosar. 1993. 191-199 pp. Geographica Slovenica, 24. Institute of Geography of the University of Ljubljana, Ljublajana.

Klementjev, Jevgeni. Karjalan kansallisten vähemmistöjen kohtalo vaa' ankielessä (The fate of the ethnic minorities of Karelia at stake). Carelia, no. 7, 1993. 128-138 pp.

Kähärä, Tellervo. How Finnish are the Thunder Bay Finns? Siirtolaisuus, vol. 21, no. 1, 1994. 20-25 pp.

Louhija, Jukka. Suomen 100-vuotiaat (The centenarians of Finland). Vanhustyö, no. 5, 1993. 17-19 pp.

Luoto, Riitta; Kaprio, Jaakko; Uutela, Antti. Age at natural menopause and sociodemographic status in Finland. American Journal of Epidemiology, vol. 139, no. 1, 1994. 64-76 pp.

Nieminen, Mauri. Väestöpyramidi - menneisyyden peili: ikääntyvän väestön kasvu ja väestöennuste (Population pyramid - mirror of the past: the population projection and the growing aging population). In: 55+: katsaus ikääntyvien elinoloihin, edited by Raija Sailas and Sirkku Mikkonen. 1994. 32-42 pp. Statistics, Finland, Helsinki.

Pitkänen, K. Ortodoksit - kiteeläinen vähemmistö (Greek-orthodoxes, a minority). In: Pitäjä rajojen mailla - Kitee ja Rääkkylä vuoteen 1870 by P. Kauppinen et al. 1994. 219-29 pp. Kitee Municipality, Jyväskylä.

Pitkänen, K. Kiteeläisten elämänkaarelta (Life cycle of Kitee people). In: Pitäjä rajojen mailla - Kitee ja Rääkkylä vuoteen 1870 by P. Kauppinen et al. 1994. 351-18 pp. Kitee Municipality, Jyväskylä.

Putkonen, Marja-Liisa. Pietarin suomalaiset (The Finns of St. Petersburg). Sukuviesti, no. 1, 1994. 7-10 pp.

Sailas, Raija; Mikkonen, Sirkku (ed.). 55+: katsaus ikääntyvien elinoloihin (55+: a study on the living conditions of the aging people). Living Condition 1994, no. 1. 1994. 157 pp. Statistics Finland, Helsinki. ISBN 951-478707-2.

Valkonen, Tapani. Työikäisen väestön vanheneminen (Aging of working-age population) In:Ikääntyminen ja työ, edited by J. Kuusinen et al. 1994. 16-26 pp. WSOY, Helsinki.
Åsheim Olsen, Venke. The Finnish minority situation in Norway. Siirtolaisuus, vol. 21, no. 1, 1994. 4-15 pp.

\section{DEMOGRAPHIC AND NONECONOMIC INTERRELATIONS}

Fellman, Johan; Eriksson, Aldur W. Biometric analysis of the multiple maternities in Finland 1881-1990. Human Biology, vol. 65, no. 3, 1993. 464-79 pp.

Jorde, L.B.; Pitkänen, K.J.; O'Brien, E.; Eriksson, A.W. Consanguinity and genetic disease in Finland's Swedish-speaking minority. In: Minority populations: genetics, demography and health, edited by A.H. Bittles and D.F. Roberts. 1992. 14-34 pp. Macmillan, London.

Hytti, Helka. Työkyvyttömyyseläkkeelle siirtymisen yhteiskunnalliset taustatekijät (Social and societal determinants of disability pension incidence). Kansaneläkelaitoksen julkaisuja M:87. 1993. 219 pp. Kansaneläkelaitos, Helsinki. ISBN 951-669-370-9. Doctoral dissertation. Sum in Eng.

Korpela, Timo. Huoltosuhde kasvaa - elatussuhde pienenee (Dependency ratio is growing - support ratio is declining). Työeläke, vol. 28, no. 1, 1993. 24-25 pp.

Lindroos, Kari. Tilastojen mies ei voi hyvin (The grim statistics of being male and Finnish). Sosiaalivakuutus, vol. 32, no. 5, 1994. 8-11 pp. Sum in Eng.

Löytönen, Markku. Growth models and the HIV epidemic in Finland. Social Science \& Medicine, vol. 38, no. 1, 1994. 179-85 pp.

Manninen, P.; Notkola, V. Maatalousyrittäjien työkyvyttömyyseläkkeelle siirtyminen $\mathrm{v}$. 1980-1990 (The disability pension incidence of the farmers in 1980-1990). In: Työterveys ja maatalous Suomessa 1992, edited by P. Susitaival. 1994. 181-98 pp. Kansaneläkelaitoksen julkaisuja ML 133. Kansaneläkelaitos, Helsinki.

Pitkänen, Kari. Historiallinen kehitys ja ihmiskunnan ravinnonsaannin turvallisuus (Historical development and nutritional security of humankind). Sosiaalilääketieteellinen Aikakauslehti, vol. 30, no. 5-6, 1993. 404-08 pp.

Pitkänen, Kari. Hylkäsivätkö perheet vanhuksensa laitoksiin? Suomalaisen laitoshoidon historiaa (Did families reject their elderly members into institutions?). In: Muuttuva vanhuus, edited by Antti Uutela and Jan-Erik Ruth. 1994. 221-36 pp. Gaudeamus, Helsinki.

Turpeinen, Oiva. Kansantaudit voitetaan lapset pelastetaan elämälle (The widespread diseases are defeated - the children survive). In: Suomalaisten tarina, 3: rakentajien aika, edited by Jaakko Itälä et al. 1993 . 18-20 pp. Kirjayhtymä, Helsinki.

Turpeinen, Oiva. Kansa terveeksi kansanterveysjärjestelmällä (Healthy people with the help of the public health system). In: 
Suomalaisten tarina, 4: järjestelmien aika, edited by Jaakko Itälä. 1993. 26-29 pp. Kirjayhtymä, Helsinki.

Vuori, Hannu. Prospects of public health around the Baltic Sea. Sosiaalilääketieteellinen Aikauslehti, vol. 30, no. 5-6, 1993. 325-33 pp.

\section{POPULATION AND FAMILY POLICIES}

Hirstiö-Snellman, Paula. Kulttuuriset ja uskonnolliset tekijät väestökysymyksessä (Cultural and religious factors in the population question). YK-tiedote, no. 1, 1994. 11-13 pp.

Hulkko, Jouko. Perhe kestää - perhepolitiikka alkaa (The family endures - family policy begins). In: Suomalaisten tarina, 3: rakentajien aika 1937-1967, edited by Jaakko Itälä et al. 1993. 21-36 pp. Kirjayhtymä, Helsinki.

Ilmakunnas, Seija. Perhetuki ja syntyvyys (Family support and fertility). Sosiaali- ja terveysministeriön julkaisuja, 10. 1994. 84 pp. Sosiaali- ja terveysministeriö, Helsinki. ISBN 952-00-0010-0. (Published also by Palkansaajien tutkimuslaitos).

Lähteinen, Martti. Perhepoliittinen tuki (Family policy support). In: Suomalainen perhe, edited by Leena Kartovaara and Hannele Sauli. 1994. 67-74 pp. Statistics Finland, Helsinki.

Majava, Altti. Itä-Euroopan väestöpolitiikka aborttipainotteista (The population policy of Eastern Europe and by abortions). YK-tiedote, no. 1, 1994. 14-15 pp.

Ministry for Foreign Affairs. International Conference on Population and Development 1994: Finland's national report on population. Publication of Ministry for Foreign Affairs, no. 13. 1993.30 pp. Ministry for Foreign Affairs, Helsinki. ISBN 951-47-8817-6.

Ollila, Eeva et al. (ed.) Vallaton väestö: kansallisia ja kansainvälisiä väestöpoliittisia kysymyksiä (Population without power: national and international questions of population policy). 1994. 250 pp. WSOY, Porvoo-HelsinkiJuva. ISBN 951-0-19875-7.

Ollila, Eeva. Väestöpoliittinen ajattelu Suomessa (Thinking in population policy in Finland). In: Vallaton väestö, edited by Eeva Ollila et al. 1994. 84-98 pp. WSOY, Porvoo-Helsinki-Juva.

Ollila, Eeva. Taistelu väestöräjähdystä vastaan (Battle against population explosion). YKtiedote, no. 1, 1994. 7-10 pp. (Also published in Sosiaalilääketieteellinen Aikakauslehti, vol. 29, no. 5-6, 1992. 300-05 pp.).

Pakolais- ja siirtolaisuusasiain neuvottelukunta. Suomen pakolais- ja siirtolaisuuspolitiikan periaatteet $=$ Principer för Finlands flykting- och migrationspolitik (Principles of Finland's refugee and migration policy). Komiteanmietintö, 5. 66+7 pp. Työministeriö, Helsinki. ISBN 951-47-7648-8.
Pitkänen, Kari. Väestöpoliittisen ajattelun kehityslinjat Suomessa (On trends in population policy thinking in Finland). Hyvinvointikatsaus, no. 1, 1994. 2-5 pp.

Tuunanen, Heikki. Väestökysymykset Suomen kehitysyhteistyössä (Population questions in the Finnish development cooperation). YK-tiedote, no. 1, 1994. 18-19 pp.

\section{N. METHODS OF RESEARCH AND ANAL- YSIS INCLUDING MODELS}

Finnäs, Fjalar. Language shifts and migration: the Finnish longitudinal census data file as an aid to social research. Tutkimuksia, no. 209. 1994. 37 pp. Statistics Finland, Helsinki. ISBN 951-47-8722-6.

Kulu, Hill. Praktisen syllogismin mallista muuttoliiketutkimuksessa (On the model of practical syllogism in migration research). Siirtolaisuus, vol. 21 , no. 1, 1994. 26-28 pp.

\section{O. THE PRODUCTION OF POPULATION STATISTICS}

Statistics Finland. Vuoden 1990 väestölaskennan luotettavuus (Reliability of the 1990 population census). Population Census 1990 , vol. 9. 1994. 128 pp. Helsinki. ISBN 951-477618-6.

Statistics Finland. Evaluation study of the 1990 census. Population Census 1990, vol. 9B. 1994. 107 pp. Helsinki. ISBN 951-727-018-6.

\section{Q. BIBLIOGRAPHIES, DIRECTORIES, AND OTHER INFORMATION SERVICES}

Ritamies, Marketta. Ehkäisyyn ja aborttiin liittyviä käsitteitä (Concepts concerning abortion and contraception). In: Raskauden keskeyttäminen - suomalaisia valintoja 1990-luvulla, edited by Matti Rimpelä and Maija Ritamo. 1993. 219-21 pp. Raportteja, no. 126. STAKES, Helsinki.

\section{S. OFFICIAL STATISTICAL PUBLICA- TIONS}

Official Statistics of Finland, Statistics Finland, Helsinki

\section{Population statistics}

Causes of death

Kuolemansyyt $=$ causes of death 1992. Health 1993, no. 9. 1993. 113 pp. In Fin, Eng with sum in Eng. 
Economic activity

Ammatti ja sosioekonominen asema $1990=$ yrke och socioekonomisk ställning = occupation and socio-economic status. Population Census 1990, vol. 8. 1993. 299 pp. In Fin, Swe, Eng with sum in Swe, Eng. ISBN 951-47-7618-6.

Työssäkäyntitilasto $1991=$ sysselsättningsstatistiken (Labor force participation statistics). Väestö 1993, no. 15. 1992. 169 pp. In Fin, Swe.

Työvoimamuutokset $=$ arbetskraftsförändringar $=$ changes in the labour force. Population Census 1990, vol. 2. 1994. 311 pp. In Fin, Swe, Eng with sum in Swe, Eng. ISBN 951-47-8702-1.

\section{Population size}

Kuntatiedot - Etelä-Suomi: Väestölaskentatietoja kunnittain = Uppgifter om kommuner Södra Finland: Folkräkningsuppgifter kommunvis (Population data by municipality - Southern Finland: census data by municipality). Population Census 1990, vol. 7A. 1993. 476 pp. In Fin, Swe. ISBN 951-47-7615-1.

Kuntatiedot - Länsi-Suomi: Väestölaskentatietoja kunnittain = Uppgifter om kommuner Västra Finland: Folkräkningsuppgifter kommunvis (Population data by municipality - Western Finland: census data by municipality). Population Census 1990, vol. 7B. 1993. 464 pp. In Fin, Swe. ISBN 951-47-7616-X.

Kuntatiedot - Keski- ja Pohjois-Suomi: Väestölaskentatietoja kunnittain $=$ Uppgifter om kommuner - Mellersta och Norra Finland: Folkräkningsuppgifter kommunvis (Population data by municipality - Middle and Northern Finland: census data by municipality). Population Census 1990, vol. 7C. 1993. In Fin, Swe. ISBN 951-47-7617-8.

Väkiluarvio kunnittain = uppskattad befolkning kommunvis 31.12.1993 (Population by municipality). Väestö 1993, no. 13. 1993. 12 pp. In Fin, Swe.

Väkilukuarvio kunnittain ja suuruusjärjestyksessä = befolkning kommunvis och i storleksordning 31.12.1993 (Population by the size of municipality). Population 1994, no. 4. 28 pp. 1994. In Fin, Swe.

\section{Population structure}

Väestörakenne $=$ befolkningens sammansättning = population structure 1993. Population 1994, no. 8. 1994. 150 pp. 1994. In Fin, Swe and Eng with sum in Eng.

\section{Vital statistics}

Väestönmuutokset $=$ befolkningsrörelsen $=$ vital statistics 1991. Population 1994, no. 2. 127 pp. 1994. In Fin, Swe and Eng.
Väestönmuutokset $=$ befolkningsrörelsen $=$ vital statistics 1992. Population 1994, no. 7. 124 pp. 1994. In Fin, Swe and Eng.

Väestönmuutokset kunnittain = befolkningsförändringar kommunvis = vital statistics by municipality 1993. Population 1994, no. 11. 1994. 54 pp. In Fin, Swe and Eng. ISBN 951727-016-X.

Population statistics and projections by other institutions

Helsingin kaupunki. Tietokeskus. Helsingin väestöennuste 1995-2020 (The population projection of Helsinki 1995-2020). Helsingin kaupungin tietokeskuksen tilastoja 1994, no. 11.67 pp. 1994. Helsinki.

Kainuun liitto. Kainuun tilastokatsaus 1993 (Statistical review of the province Kainuu 1993). Julkaisu, B, no. 13. 1993. 74+9 pp. Kajaani. ISBN 951-9321-50-0.

Meriläinen, Jouni; Gissler, Mika; Hemminki, Elina; Teperi, Juha. Perinataalitilastot 1991 $=$ Finnish perinatal statistics 1991. STAKES National Research and Development Centre for Welfare and Health. Health 1993, no. 7. 1993. 59 pp. ISBN 951-47-7725-5. In Fin, Eng with sum in Eng.

Ruusinen, Anneli; Virtanen, Martti; Gissler, Mika. Syntyneet lapset ja äidit Suomessa vuosina $1987-1992$ = babies and mothers in Finland 1987-1992. Tilastotiedote 1994, no. 18.32 pp. 1994. STAKES Sosiaali- ja terveysalan kehittämiskeskus, Helsinki.

Väestörekisterikeskus. Suomen asukasluku: vuoden vaihde 1993/1994 = Finlands invånartal: årskiftet 1993/1994. (The size of the Finnish population 1993/1994). 1994. 42 pp. Väestörekisterikeskus, Helsinki.

\section{Sources}

The collections of the library of the Population Research Institute of Väestöliitto

The Finnish databases KATI and KOTI

The US database POPLINE

Nordic Demography, vol. 20, 1995

Population Index, vol. 59, 1993, nos. 3-4; vol. 60,1994 , nos. $1-4$.

Suomen kirjallisuus, 1993, nos. 11,12; 1994, nos. $1-12 ; 1995$, nos. $1-5$

Index

Alitolppa-Niitamo, Anne - H1

Asker, Bjorn - $\mathrm{H} 1$

Birt, Hazel Lauttamus - H1

Csernak, J. - G

Domander, Minna - H1

Ehnholm, Christian - E

Engman, Max - H1

Eriksson, Aldur W - L, H2

Fellman, Johan - L 
Finnish American Historical Society of the West $-\mathrm{H} 1$

Finnäs, Fjalar - N

Gissler, Mika - S

Hakovirta, Harto - $\mathrm{H} 1$

Hartikainen-Sorri, Anna-Liisa - F

Heikkilä, Elli (former Karjalainen) - C, J, H1, $\mathrm{H} 2$

Helsingin kaupunki - S

Hemminki, Elina - S

Hirstiö-Snellman, Paula - H1, M

Hulkko, Jouko - G, J, M

Husa, Ritva - C

Hytti, Helka - L

Häggman, Kai - G

Häikiö, Martti - H1

Hämynen, Tapio - H2

Ilmakunnas, Seija - M

Jorde, L.B. - L

Jousilahti, Pekka - E

Juntunen, Kaisa - F

Jussila, Heikki - C

Jutikkala, Eino - D, I

Kainuun liitto - S

Kannisto, Väinö - E

Kaprio, Jaakko - J

Karjalainen (Heikkilä), Elli - J, H1, H2

Kartovaara, Leena - G

Karvonen, Martti J - E

Kavén, Pertti - H1

Klementjev, Jevgeni - J

Koivukangas, Olavi - $\mathrm{H} 1$

Kokkonen, Paula - F

Koponen, Päivikki - F

Korhonen, Sirpa - H2

Korkiasaari, Jouni - H1

Korpela, Timo - L

Koskinen, Arja - H1

Koskinen, Seppo - A, E

Kosunen, Elise - F

Kultalahti, Olli - H1

Kulu, Hill - N, H1

Kähärä, Tellervo - J

Laakkonen, Risto - H1

Laakso, Seppo - D

Laari, Outi - H1

Lehtiniemi, Anne - G

Leino, P. - E

Leino-Arjas - E

Liebkind, Karmela - H1

Lindgren, Jarl - D, G

Lindroos, Kari - L

Linna, Pirkko - G

Louhija, Jukka - J

Luoto, Riitta - J

Lähteinen, Martti - M

Lönnqvist, Jouko - E

Löytönen, Markku - L

Majava, Altti - H1, M

Maki, Jeanne C. - H1

Malinen, Pekka - D

Manninen, P. - L
Markkola, Pirjo - G

Martelin, Tuija - A, E

Martikainen, P. - E

Meriläinen, Jouni - S

Mielke, James H. - E, F, H2

Miettinen, H. - E

Mikkonen, Sirkku - J

Ministry for Foreign Affairs - M

Moring, Beatrice - G

Mustaniemi, H. - E

National Research and Development Centre for

Welfare and Health $-\mathrm{F}$

Nieminen, Mauri - D, J, H1

Nikander, Timo - G

Nissinen, Aulikki - E

Notkola, Veijo - A, D, E, L

Notkola, Irma-Leena - A, F

O'Brien, E. - L

Ojanperä, Satu - H2

Ollila, Eeva - M

Pajunen, Airi - E

Pakolais- ja siirtolaisuusasiain neuvottelukunta

$-\mathrm{M}$

Palomäki, H. - E

Pansar, Sven - E

Parkkinen, Pekka - D

Pekkanen, Juha - E

Pennanen, Helena - $\mathrm{H} 1$

Pitkänen, Kari - A, B, E, H1, I, J, L, M

Puska, Pekka - E

Putkonen, Marja-Liisa - J

Pyörälä, K. - E

Relethford, John H. - F, H2

Rikkinen, Kalevi - H2

Rimpelä, Matti - F

Rimpelä, Arja - F

Ritamies, Marketta - F, G, Q

Ritamo, Maija - F

Runblom, Harald - H1

Runtti, Susanna - H1

Ruusinen, Anneli - S

Ryynänen, Markku - D

Saarelainen, Asko - H2

Sailas, Raija - J

Salmi, Lauri - F

Salomaa, V. - E

Salonen, Jukka T.- E

Sauli, Hannele - G

Savela, S. - E

Segerstrål, Boris - C

Sosiaali- ja teryeysalan kehittämis- ja

tutkimuskeskus - F

Statistics Finland - O, S

Suni, Leo - H1

Syrjälä, Jaana - A

Säntti, Riitta - D

Säävälä, Minna - F

Söderling, Ismo - H1

Taimio, Hilkka - F

Takalo, Pirjo - H1

Teperi, Juha - S

Toivonen, Juhani - F 
Tuomilehto, Jaakko - E Turpeinen, Oiva - L Tuunanen, Heikki - M Uitto, J.I. - F

Uutela, Antti - J

Valkonen, Tapani - A, E, J

Valtonen, Kathleen - H1

Vartiainen, Erkki - E

Veikkola, Eeva-Sisko - G

Verigin, Sergei - H1

August 14, 1995
Vikat, Andres - G

Virtanen, Martti - S

Vuorenmaa, Hilkka - F

Vuori, Hannu - L

Väestöliitto - F

Väestörekisterikeskus - S

Walter, Hannes - H1

Åsheim, Venke - J

Österman, O-E 